\title{
Use of Topographic Map Evidence From Drainage Divides Surrounding Wyoming's Great Divide Basin to Compare Two Fundamentally Different Regional Geomorphology Paradigms
}

\author{
Eric Clausen \\ Correspondence: Eric Clausen, 100 West Ave D-17, Jenkintown, PA 19046, United States. \\ E-mail: eric2clausen@gmail.com \\ Received: October 28, 2019 \\ Accepted: December 27, 2019 \\ Online Published: January 11, 2020 \\ doi:10.5539/esr.v9n1p45 \\ URL: https://doi.org/10.5539/esr.v9n1p45
}

\begin{abstract}
Divide crossings (or low points or gaps) notched into the North American east-west continental divide segments completely encircling Wyoming's Great Divide Basin interior drainage region (as observed on detailed topographic maps) are used to compare the commonly accepted regional geomorphology paradigm with a fundamentally different and new regional geomorphology paradigm. Paradigms are sets of rules governing how a scientific discipline conducts its research and are judged on their ability to explain observed evidence. Published literature is used to contrast an accepted paradigm interpretation that east-oriented drainage previously flowed across what is now the Great Divide Basin with the new paradigm basic requirement that mountain range and continental divide uplift occurred while immense south-oriented floods flowed across them. Numerous divide crossings are notched into the continental divide segments now completely encircling the relatively flat-floored Great Divide Basin interior drainage area and divide crossings observed along each of the Great Divide Basin's north, east, south, and west margins are described and interpreted first from the accepted paradigm perspective (using published literature interpretations to the extent possible) and second from the new paradigm perspective. The published literature does not mention most of the described divide crossings, much less provide explanations for their origins, perhaps because the accepted paradigm cannot satisfactorily explain those origins. In contrast the new paradigm successfully explains most if not all of the described (and observed, but undescribed) divide crossings, although the new paradigm requires a completely different middle and late Cenozoic regional geologic history than what most published regional geology literature describes.
\end{abstract}

Keywords: Continental Divide, Crooks Gap, drainage divide crossings, Leucite Hills, Muddy Gap, Sinclair Gap, Wamsutter Gap, Wyoming

\section{Introduction}

\subsection{Statement of the Problem}

Southwestern Wyoming's Great Divide Basin (seen in figure 1) is a closed basin, approximately $10^{4} \mathrm{~km}^{2}$ in size and is located in a high-altitude desert region along North America's east-west continental divide. The encircling continental divide extends from the much higher Wind River Mountains (northwest) to the much higher Sierra Madre Mountains (southeast) and separates the closed basin from the North Platte River drainage basin (north and east and draining eventually to the Gulf of Mexico) and from Colorado River tributary drainage basins (south and west and draining to the Pacific Ocean). Heller et al (2010, p. 150), working from the commonly accepted middle and late Cenozoic regional geology paradigm (accepted paradigm) perspective, suggest "climate change, through its impact on erosion and flexure, provides the primary mechanism of basin closure." In contrast, Clausen (2019a and 2019b), working from a new and fundamentally different middle and late Cenozoic regional geology paradigm (new paradigm) perspective suggests what is now the Wyoming east-west continental divide originated when a thick continental ice sheet caused crustal warping to raise what are now high plateau areas and mountain ranges as massive south-oriented continental ice sheet meltwater floods flowed across them.

Heller et al (p. 152) also state "Total relief within the [closed] basin is significant... However, on average, the basin is quite flat" with an average elevation of about $2100 \mathrm{~m}$ above sea level and "the lowest gaps along the basin divide include Wamsutter Gap (2051 m), Muddy Gap (2066 m), Sinclair Gap (1996 m), and Sand Gap (2097 m)..., and thus these are the minimum spillover elevations." Heller et al further note (p. 152), "Bedrock exposed among the dunes at Sand Gap is at an elevation of $1990 \mathrm{~m}$ which is slightly lower than the elevation of the divide at Sinclair Gap." For this 
reason, Heller et al consider Sand Gap to have been the last Great Divide Basin outflow location. In contrast, the new paradigm requires (unless there is good reason to believe otherwise) all gaps or low points along a drainage divide (also referred to here as divide crossings) to have been eroded by water flowing in one direction or the other and the new paradigm rule is the Missouri River drainage system developed as valleys eroded headward across immense south- and southeast-oriented continental ice sheet meltwater floods (implying meltwater floods from a continental ice sheet once flowed across the Great Divide Basin). This new paradigm defining rule is impossible from the accepted paradigm perspective, meaning the two paradigms are fundamentally different.

Scientific paradigms according to Kuhn (1970) are frameworks of rules governing how a specific discipline conducts its research and the paradigms by themselves are neither correct nor incorrect. A paradigm enables researchers to explain evidence and to open up research opportunities, but also identifies anomalous evidence the paradigm rules cannot satisfactorily explain. Kuhn suggests anomalous evidence is dealt with in one of three ways. First, the accepted paradigm eventually explains the evidence and the paradigm continues without serious interruption. Second, the anomalous evidence is shelved for future consideration. Third, the anomalous evidence leads to a new paradigm and a battle over which paradigm should be used. In such a battle Kuhn suggests one paradigm should not judge the other, but instead the competing paradigms should be evaluated based on their abilities to explain evidence.

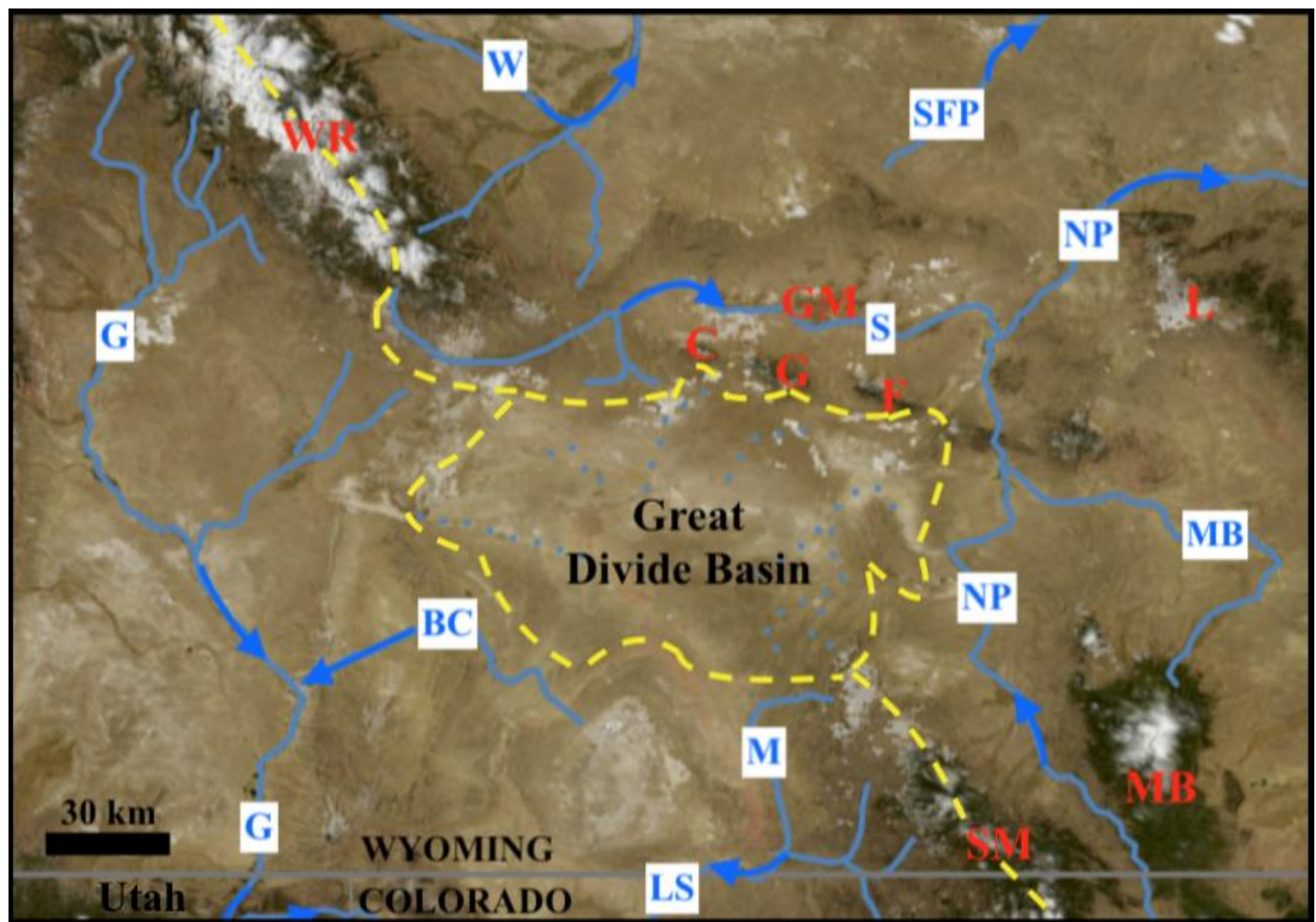

Figure 1. Modified imagery from United States Geological Survey (USGS) National Map website showing Great Divide Basin location and the east-west continental divide (dashed yellow line). Blue letters identify drainage routes: BC-Bitter Creek, G-Green River, LS-Little Snake River, M- Muddy Creek, MB-Medicine Bow River, NP-North Platte River, S-Sweetwater River, SFP-South Fork Powder River, W-Wind River. Red letters identify mountains: C-Crooks Mountain, F-Ferris Mountain, G-Green Mountain, GM- Granite Mountains, L-Laramie Range, MB-Medicine Bow Mountains, SM-Sierra Madre Mountains, WR-Wind River Range

Heller et al only mention four gaps or divide crossings, yet topographic maps show numerous other divide crossings along continental divide segments now encircling the Great Divide Basin and these other divide crossings all link Great Basin low areas (and sub-basins) with external drainage basins. Heller et al do not explain why only four divide crossing are mentioned or why their paper for all practical purposes ignores three of those four mentioned divide crossings, although it is possible the accepted paradigm rules do not permit satisfactory explanations for those other divide crossings. This paper briefly describes several of the numerous divide crossings (including those in the Heller $e t$ al paper) that are notched into continental divide segments encircling the Great Divide Basin and attempts to explain those divide crossings from the accepted and the new paradigm perspectives. Finally, Occam's Razor, which in science 
according to Anderson (2002, p. 57) says "what can be done with fewer [assumptions] is done in vain with more," is used to compare the two fundamentally different paradigm explanations.

\subsection{Geographic Setting}

The previously mentioned figure 1 shows the Great Divide Basin location in relation to surrounding drainage routes and mountain ranges (note the Wyoming border with Colorado and Utah near the bottom). The dashed yellow line shows the east-west continental divide that follows the Wind River Mountains crest in a northwest-to-southeast direction before splitting to encircle the Great Divide Basin and then to again become a single drainage divide along the Sierra Madre Mountains crest. The Green River drainage basin with its water eventually reaching the Colorado River and the Pacific Ocean is located to the west and south of the Great Divide Basin (the Little Snake River flows to the Yampa River, which then flows to the Green River). The North Platte River is located to the east of the Great Divide Basin where it flows in a north direction before turning in an east direction with its water eventually reaching the Missouri River and ultimately the Gulf of Mexico. To the north of the Great Divide Basin is the narrow east-oriented Sweetwater River drainage basin, which drains to the North Platte River, while further to the north the Wind River turns abruptly from flowing in a southeast direction to flow in a north direction with its water eventually reaching the Missouri River and water in the north-oriented South Fork Powder River also eventually reaches the Missouri River.

\subsection{Previous Work}

For paradigm comparisons previous work needs to be subdivided into three groups. The first group presents observed evidence requiring explanations regardless of the paradigm used. Detailed topographic maps like those at the United States Geological Survey (USGS) National Map website are examples of paradigm-neutral previous work. Geologic maps, such as the Love and Christiansen (1985) Geologic Map of Wyoming, also record paradigm-neutral observations, although paradigm-influenced interpretations are sometimes included. Further, published geologic reports contain paradigm-neutral observations such as the Conroy et al (2008, p. 751) statement that the Great Divide Basin is underlain by "a syncline with well over a thousand meters of mostly flat-lying sedimentary rocks of the Paleocene Fort Union Formation and the Eocene Wasatch, Green River, and Bridger formations overlying Cretaceous rocks of the Mesa Verde Group." Steidtmann et al (1989, p. 39) also provide paradigm neutral evidence by observing that volcanic clasts now found in "middle Eocene Bridger Formation" conglomerates that had been moved by a south-oriented drainage system across what are now the high Wind River Mountains from the Absaroka volcanic field (in the north) to what is now the upper Green River drainage basin.

Reports written from the accepted paradigm perspective represent a second previous work type. To explain how rivers cut deep canyons across Wyoming mountain ranges a Mears (1993, p. 609) literature review says. "At the climax of the Laramide orogeny, during the latest Paleocene and earliest Eocene, the relief of the mountains exceeded that of the present. ...in the early mid-Eocene, the crests of the mountains were lowered by erosion and the mountain valleys and broad intermontane basins were filled. The basin deposits were partially excavated during a widespread late Eocene interval of regional erosion that preceded the onset of renewed basin filling in the latest Eocene. During the ensuing aggradation, clastic debris derived from the mountains was overwhelmed by ash from distant volcanic eruptions. The rising level of Oligocene and then Miocene deposits eventually lapped across the lower segments of the crystalline-cored uplands that finally had been eroded down to broad subsummit surfaces surmounted by residual hills and peaks." Following the filling of the intermontane basins and the near burial of the mountains Mears continues by saying a broad regional uplift and exhumation of the broad basin floors began. Based on such an accepted paradigm interpretation Lillegraven and Ostresh (1988, p. 320) determined that "Because of the extensive early Oligocene infillings of Wyoming's basins, a basic eastwardly grained drainage pattern... was established" and include a map showing early Oligocene east-oriented drainage routes crossing what is now the Great Divide Basin and flowing to an ancestral north- and east-oriented North Platte River drainage route (roughly following its present-day alignment).

Many accepted paradigm interpretation details remain unknown. Flanagan and Montagne (1993, p. 597) state, "The depth and timing of Wyoming's basin fill remains a controversial subject. The essential question is whether Wyoming's foreland basins were filled with volumetrically more Cenozoic sedimentary material between late Eocene and Pleistocene and then substantially excavated or whether the material in the basins today is the maximum sediment fill deposited in the basins throughout the Cenozoic," although they also say (p. 598) "The superposition of river systems suggest that these rivers were flowing across basins filled with sedimentary material to elevations of approximately $9,000 \mathrm{ft}$. (2700 m)." Fan et al (2014, p. 547) suggest "When and how the central Rocky Mountains (Rockies) of western North America gained modern topography remains a controversial question" and then suggest "the region underwent differential uplift to form relief similar to that of today before earliest Oligocene time." Heller et al (2010, p. 150) state "during the early part of the Laramide orogeny, [the Great Divide] basin was part of the greater Green River Basin" and that "The basin was not closed, however, until at least middle to late Miocene time." They further suggest "closure of 
the Great Divide Basin took place with no internal faulting, nor did it require any extrabasinal tectonic activity to force its closure."

In spite of unanswered questions Hansen (1986, p. 67) suggests, "by late Eocene or early Oligocene time... Drainage out of the Green River Basin was presumably eastward, across the present continental divide... The Great Divide Basin rose so much in late Pliocene time that it was largely stripped of post-Eocene rocks (Love, 1971). As the eastern Uinta Mountains subsided, moreover, the new drainage along and across the range gradually extended its watershed, and the Upper Green River finally was captured near the present mouth of Bitter Creek." Hansen further notes "late Tertiary and Quaternary uplift of the Continental Divide across southern Wyoming probably was partly responsible for the Upper Green's capture and diversion," and (p. 69) "the capture may have been a middle Pleistocene event, although modern indigenous fish species in the Upper Green River drainage differ markedly from those in the North Platte and Sweetwater." Hansen and Lillegraven and Ostresh do not address Love's (1970, p. C119) observation that a south-oriented late Eocene "powerful river from the Absaroka Range continued to flow southeastward along the west margin of the Granite Mountains and into the Great Divide basin" and that "Boulders of Tertiary igneous rocks as much as 8 feet $(2.4 \mathrm{~m})$ in diameter were carried 90 miles $(145 \mathrm{~km})$ or more and deposited along the stream valley. The volume of water and the stream velocity and gradient necessary to move boulders of this size a distance of 90 miles (145 km) should be investigated further."

The third type of previous work addresses the new paradigm and to date is limited to Clausen's 2017-2019 publications. These publications define the new paradigm with a rule that says today's Missouri River drainage basin developed as deep valleys eroded headward from the Mississippi River valley and from what was a continental ice sheet location across and along immense south- and southeast-oriented floods. This definition (which from the accepted paradigm perspective did not and could not have happened) forces recognition of a North American continental ice sheet thick and heavy enough to create a deep "hole" by deeply eroding the bedrock under it and by causing crustal warping elsewhere on the continent that raised what are now mountain ranges and high plateau areas as immense meltwater floods flowed across them. Clausen (2019a and 2019b) states prior to drainage reversals that caused the melt water floods to flow into deep "hole" space being opened up by ice sheet melting, south-oriented melt water floods flowed across what is now the Bighorn-Wind River drainage divide and into the Wind River Basin and then southward across the east-oriented Sweetwater River drainage basin and the Great Divide Basin to reach the Colorado River and the Pacific Ocean. Several other recent papers demonstrate how the new paradigm explains previously unexplained topographic map evidence for more than 15 specific northern Missouri River drainage basin geographic regions, some of which are summarized in Clausen (2018a, 2018b, and 2019c), while other papers such as Clausen (2018c and 2019d) demonstrate how the new paradigm explains previously unexplained mountain pass and valley origins.

\section{Research Method}

This paper is one of several being written to demonstrate how the new paradigm explains previously unexplained detailed topographic map evidence. After more than 20 years investigating anomalous drainage evidence a decision was made to spend three years (1999-2001) using map interpretation techniques to study large mosaics of detailed hard copy USGS and Canadian Geological Survey topographic maps so as to systematically cover the entire Missouri River drainage basin and several adjacent drainage basins to determine how all drainage divides between streams (shown on the maps) originated. Conclusions reached during that Missouri River drainage basin landform origins research project were unexpected and fundamentally different from anything in the published scientific literature, but could not easily be demonstrated to skeptical reviewers. The first three-year investigation was repeated during the 2011-2013 time period using National Geographic TOPO digital maps and software and more than 500 research notes in blog format now describe origins for almost 4000 different Missouri River drainage basin drainage divides and can be found at geomorphologyresearch.com.

New paradigm development relied on detailed topographic map interpretation to identify drainage divides and low points (divide crossings) along those divides which are interpreted (unless there is good reason to believe otherwise) to be places where water once crossed the divide. The low points typically link valleys now draining in different directions, suggesting water in one of those valleys has reversed its flow direction. Detailed topographic maps are used to study downstream areas to determine why flow in one valley was reversed. Frequently, but not always, the reversed flow valley now drains to a deeper valley as a barbed tributary suggesting the deeper valley beheaded and captured flow that had been once moving across the drainage divide. The large number of divide crossings (observable on detailed topographic maps along most drainage divides) are then used to reconstruct former drainage routes, which almost always suggest large complexes of diverging and converging channels once crossed the studied drainage divides. The diverging and converging channels are next interpreted to be flood formed anastomosing channel complexes, which can be followed both downstream and upstream (using divide crossings and stream capture evidence observable on detailed topographic maps). Detailed topographic maps of mountainous and high plateau areas when studied using such map 
interpretation techniques provide good evidence that the mountains and plateau areas must have been rising as the floodwaters flowed across them, which caused the floodwaters to be systematically diverted to flow in different directions.

Research related to the project reported here used detailed topographic maps and tools available at the USGS National Map website. Drainage divides surrounding the Great Divide Basin were identified and studied to locate gaps or divide crossings where water flowing in one direction or the other had once crossed into and/or out of the Great Divide Basin. Detailed topographic maps covering Great Divide Basin interior regions were also studied to identify pathways across what are now shallow closed basins within the Great Divide Basin that might have served as flow routes for water moving between various sets of divide crossings. Previous investigator published reports were reviewed to search for references identifying any of the observed divide crossings and any discussions related to the origins of those mentioned divide crossings. Published literature was also reviewed to note references suggesting that drainage routes once flowed into and/or out of what is now the Great Divide Basin and the suggested directions and routes of flow. While the reviewed literature only mentioned a few gaps or divide crossings the map study observed numerous divide crossings, far too many to describe in this finite paper. What were regarded to be the most significant divide crossings (including all divide crossings or gaps mentioned in the reviewed literature) were then briefly described in the results section below. Accompanying those descriptions are attempts to explain the described divide crossings first from the accepted paradigm perspective (using previous investigator interpretations if available) and second from the new paradigm perspective (also based on published literature information if available).

\section{Results}

\subsection{Divide Crossings Along the Great Divide Basin's Northern Margin}

The Great Divide Basin is bounded on the north (from the northwest to the southeast) by Crooks Mountain, Sheep Mountain (a relatively small upland), Green Mountain, and the Ferris Mountains with the Seminoe Mountains (unlabeled in figure 1) located to the east of Ferris Mountain. Alkali Creek is the north-oriented Sweetwater River tributary shown in figure 1 (but unlabeled) to the west of Crooks Mountain and flows from the Great Divide Basin northern margin in the wide gap between the Wind River Mountains and Crooks Mountain. Cyclone Rim is an arcuate shaped ridge with elevations ranging from about 2140 to 2240 meters that for a distance of more than 10 kilometers forms the low drainage divide between northeast-oriented West Alkali Creek and south-oriented drainage routes leading into the Great Divide Basin. Northeast-oriented East Alkali Creek drains the south slope of the western two-thirds of Crooks Mountain with low points along the East Alkali Creek-Great Divide Basin drainage divide being in the 2170-meter range. High points at the east end of Crooks Mountain seen in figure 2 exceed 2500 meters, but further to the west several deep divide crossings notched into the Crooks Mountain upland have floor elevations in the 2230- to 2280-meter range. Arapahoe Creek headwaters (seen in figure 2) originate on the south side of the Crooks Mountain highest ridges and Arapahoe Creek is a south-oriented stream flowing into the Great Divide Basin's Lost Creek Basin, which is a shallow Great Divide Basin closed basin, while the north side of the Arapahoe Creek headwaters (and the Crooks Mountain highest points) is drained by several north-oriented Sweetwater River tributaries.

Crooks Creek is the north-oriented Sweetwater River tributary flowing through Crooks Gap (seen in figure 2) and drains the western two-thirds of the Green Mountain southwest slope and small areas along the Crooks Mountain south and east flanks. A 100-meter deep divide crossing is located between Sheep Mountain and Green Mountain. Crooks Creek originates as a south-oriented stream near the Green Mountain southeast end (see figure 3) and flows in a north direction between Crooks Mountain and Sheep Mountain after flowing in a northwest direction along the Green Mountain southwest flank where southwest-oriented tributaries draining much of the Green Mountain southwest slope join it. Elevations along the West Fork Crooks Creek-Arapahoe Creek drainage divide (seen in figure 2) are as low as 2130 meters while elevations along the Sweetwater River-Arapahoe Creek drainage divide rise to more than 2500 meters and further to the east and southeast elevations at the Green Mountain southeast end (seen in figure 3) along the Sweetwater River-Great Divide basin drainage rise to 2812 meters at Whiskey Peak (at the Green Mountain southeast end). North-oriented Muddy Creek flows between Green Mountain and the Ferris Mountains and like Crooks Creek flows from the Great Divide Basin northern margin with south-oriented tributaries draining the Green Mountain eastern end and much of the Ferris Mountains southwest slope. Further to the east south-oriented streams drain a section of the Ferris Mountains south flank directly into the Great Divide Basin while southeast-oriented Sand Creek headwaters drain the eastern end of the Ferris Mountains south slope and then turn to flow in a north direction.

Previous investigators working from the accepted paradigm perspective have not addressed how drainage systems in the Sweetwater River-Great Divide Basin drainage divide area originated. For example, Jaworowski (1991, p 417) states "tributaries to the Sweetwater River flowed northward from Green Mountain during Quaternary time" but makes no mention of how those drainage routes originated. Rackley (1972, p. 756), who was most interested in the regional 
uranium deposits states "With renewed uplift in early Eocene time... an apron of alluvial fans spread southward into the Great Divide basin" in the area to the south of Crooks Gap (between Crooks Mountain and Green Mountain) and of Muddy Gap (between Green Mountain and the Ferris Mountains), but makes no mention of how the present-day north-oriented Alkali, Crooks, Muddy, and Sand Creek drainage systems evolved. Heller et al (2010, p. 150-2) while mentioning, but not discussing Muddy Gap and two other gaps consider the Sand Creek drainage route to have been the last Great Divide Basin outlet and state "Continued erosion in the surrounding drainage led to flexural rebound, against which erosion by the outlet from the Great Divide Basin was unable to compete," but do not explain how the present day Alkali, Crooks, Muddy Creek drainage systems originated. These and other investigators ignored most of the Sweetwater River-Great Divide Basin drainage divide area gaps or divide crossings, perhaps because the accepted paradigm provides no good way to determine how the large numbers of gaps or divide crossings originated.

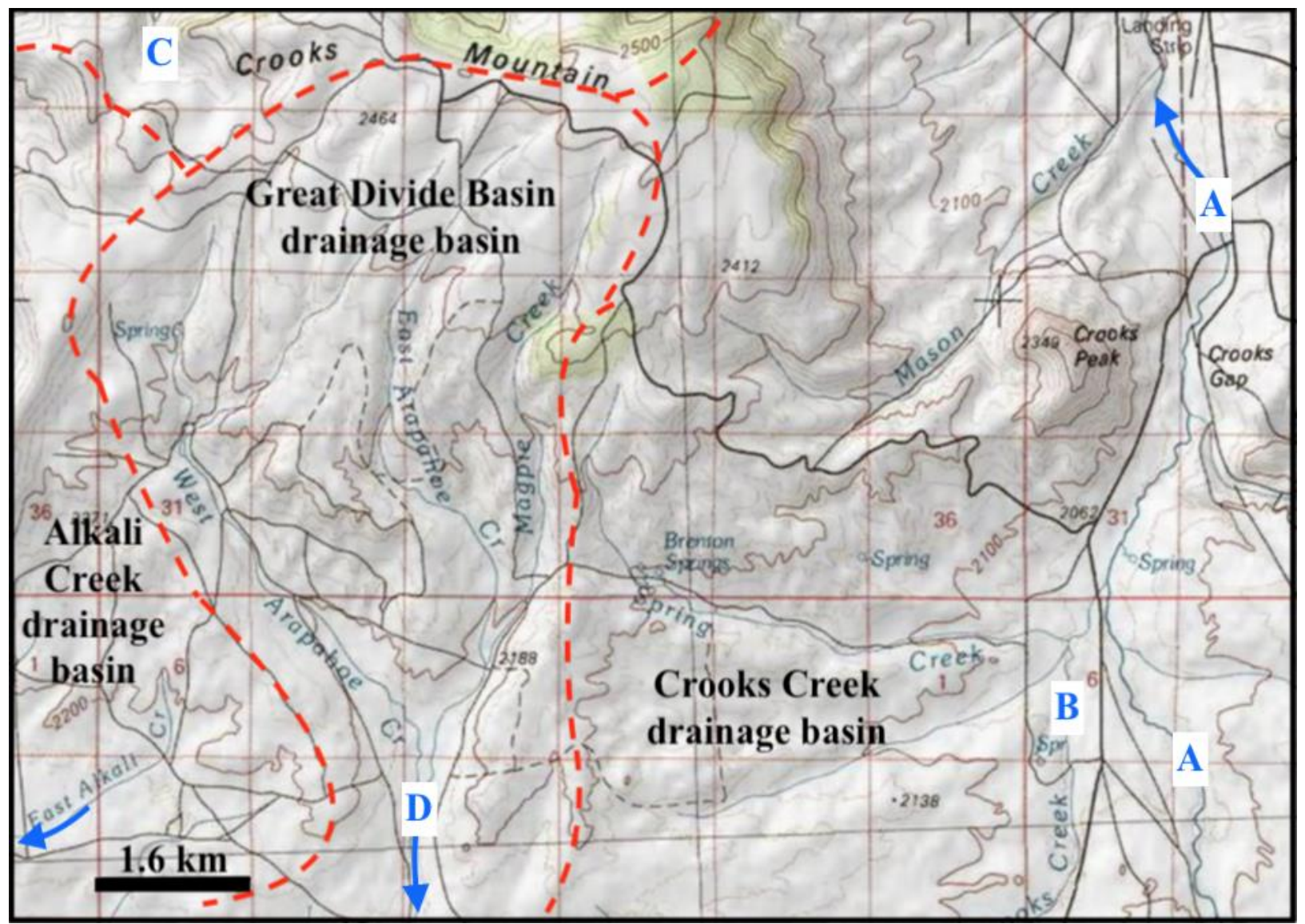

Figure 2. Modified topographic map from USGS National Map website showing drainage routes at and near tCrooks

Mountain southeastern end. Letters identify: A-north-oriented Crooks Creek, B-West Fork Crooks Creek, C-area drained by north- and northeast-oriented Sweetwater River tributaries, D-Arapahoe Creek draining into Great Divide Basin. Unlabeled blue arrow in southwest corner shows East Alkali Creek headwaters. Contour interval is 20 meters

In contrast Clausen (2019b), who worked from the new paradigm perspective, described topographic map evidence showing where immense south-oriented floods had once crossed the present-day Wind River-Sweetwater River drainage divide and includes the statement (p. 410) "the east-oriented Sweetwater River drainage basin is located along a deep 'hole' rim segment, with the deep 'hole' rim in Montana, Wyoming, and northern Colorado following the present-day east-west continental divide" and (p. 417) "deep 'hole' rim uplift enabled the shallow east- and northeast-oriented Sweetwater River valley to erode headward across the south-oriented flood flow channels and caused flow reversals on north ends of the beheaded channels to create north-oriented Sweetwater River tributaries and the Sweetwater River-Great Divide Basin drainage divide." Such a scenario explains the above described topographic map evidence including the water gaps, wind gaps, drainage routes, and drainage divides. The Alkali, Crooks, Muddy, and Sand Creek drainage systems seen today originated when uplift of the Sweetwater River-Great Divide Basin drainage divide area enabled the Sweetwater River valley to erode headward across the south-oriented flood flow and forced the beheaded south-oriented flood flow channels that had been moving water into what is now the Great Divide Basin to reverse their flow direction and to create what are today north-oriented Sweetwater River tributaries with south-oriented headwaters and tributaries. 


\subsection{Divide Crossings Along the Great Divide Basin's Eastern Margin}

At the north end of the Great Divide Basin's eastern margin Sand Creek after originating as a southeast-oriented stream turns and flows in a north direction through a 300-meter deep canyon separating the Ferris Mountains southeast end from Bear Mountain (to the east) and then turns in a northeast direction to join the North Platte River. A somewhat wider and dry southwest-to-northeast oriented valley, almost as deep, separates Bear Mountain from Junk Hill along with other less deep divide crossings in the Seminoe Mountains also link the Great Divide Basin with northeast-oriented North Platte River tributaries. Further to the south Windy Ridge, Cheyenne Ridge, and Coal Creek Rim form zig-zagging hogback ridges that roughly follow the Great Divide Basin-North Platte River drainage divide and link the Seminoe Mountains with the Haystack Mountains. Divide crossings notched into these ridges also suggest water once flowed across the Great Divide Basin-North Platte River drainage divide. The deepest of these divide crossings is cut across Coal Creek Rim and has almost the same floor elevation as Sand Creek Gap (about $2100 \mathrm{~m}$ ). Still further to the south Sinclair Gap (seen in figure 4) is located near the south end of a broad flat-floored and roughly north-northwest to south-southeast oriented structural valley between the Haystack Mountains (east) and the Rawlins Uplift (west) that links Separation Flats in the Great Divide Basin (to the north) with the north-oriented North Platte River valley. Separation Lake (in a Separation Flats area extending southward between the Rawlins Uplift and the Haystack Mountains) is near the south-southeast end of a series of shallow closed basins extending from figure 3 to Sinclair Gap. Great Divide Basin drainage routes seen in figure 3, if they had sufficient volumes of water, would flow across the Great Divide Basin's eastern margin in a south-southeast direction to Sinclair Gap and then to the North Platte River. Based on present-day floor elevations Sinclair Gap $(1996 \mathrm{~m})$ is the lowest point on drainage divides surrounding the Great Divide Basin (although Heller et al say the bedrock channel under Sand Creek Gap area sand dunes is 6 meters lower).

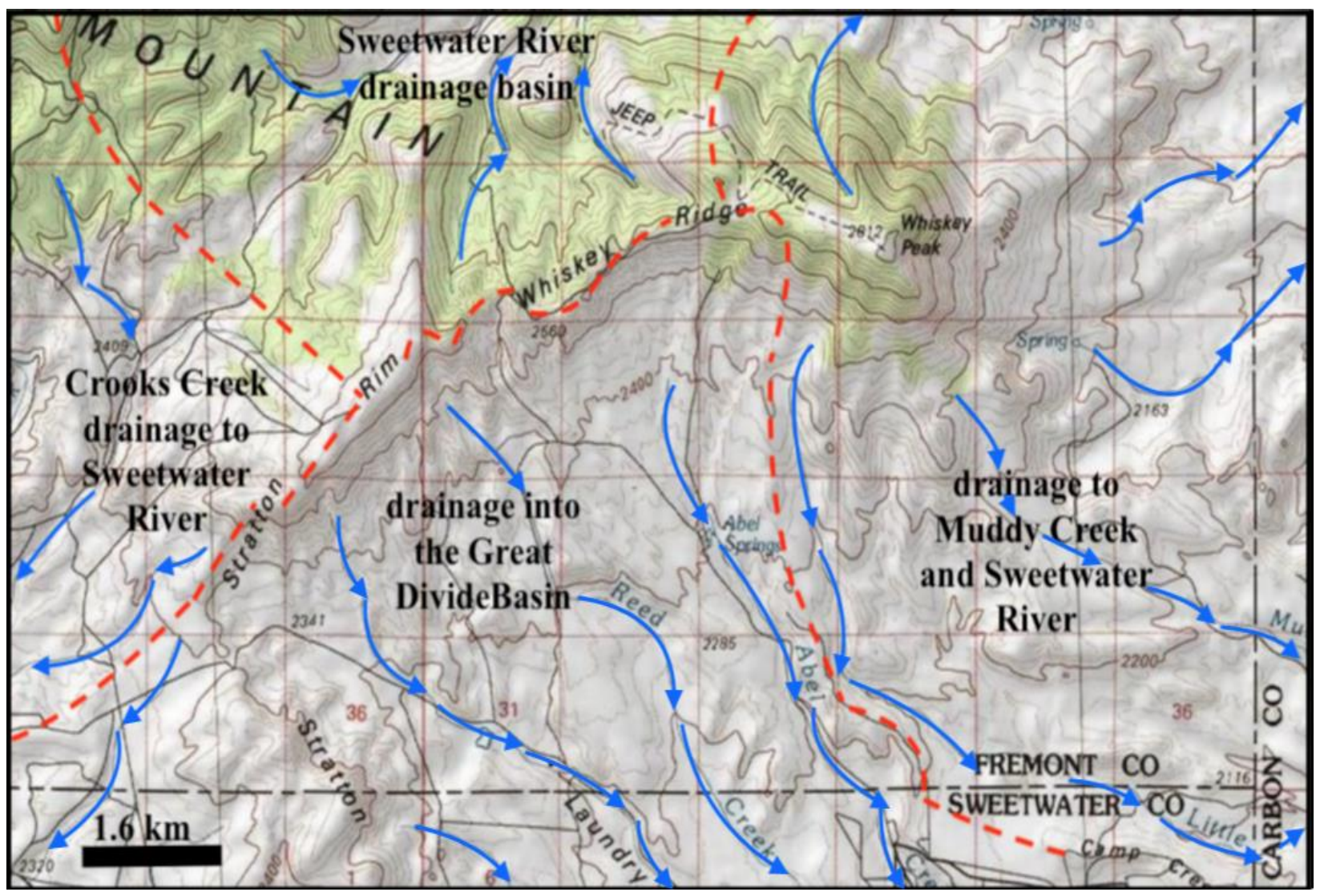

Figure 3. Modified USGS topographic map showing major drainage divides (dashed red lines) in the Green Mountain

southeast end area. Blue lines and arrows show major drainage routes and directions. Contour interval is 20 meters

Within the Great Divide Basin Separation Creek begins as a southwest-oriented stream on a Cretaceous Lance Formation surface near the south end of Great Divide Basin's eastern margin (McLaughlin and Fruhwirth, 2008) and then makes a U-turn to flow in a north direction on a route west of the Great Divide Basin's eastern margin and along the Rawlins Uplift west side before cutting across dipping Tertiary and Cretaceous stratigraphic units and making a U-turn to flow around the Rawlins Uplift north end and then in a south direction between the Rawlins Uplift and Haystack Mountains to end at Separation Lake (in a shallow closed basin about 15 kilometers to the northwest of figure 
4). A well-defined 200-meter deep dry valley (floor elevation slightly less than 2200 meters) links the south end of the north-oriented Separation Creek valley with south-oriented Alamosa Gulch draining to Muddy Creek in the Colorado River drainage basin and suggests water once flowed in one direction or the other between the present-day Colorado River drainage basin and the Great Divide Basin. Further to the north the City of Rawlins is located on the north side of a well-defined west-to-east oriented divide crossing linking the Great Divide Basin's Separation Creek drainage basin with east-oriented Sugar Creek flowing to the North Platte River (seen in figure 4). The Rawlins divide crossing has a floor elevation of slightly more than 2110 meters and suggests possible erosion by east- or west-oriented anastomosing channels. Today that divide crossing is used as a major east-to-west highway, railroad, and pipeline route. Other Great Divide Basin eastern margin divide crossings, most with higher floor elevations are too numerous to discuss and suggest multiple streams of water once flowed between the Separation Creek drainage basin (in the Great Divide Basin) and the North Platte River drainage basin (now draining to the Gulf of Mexico).

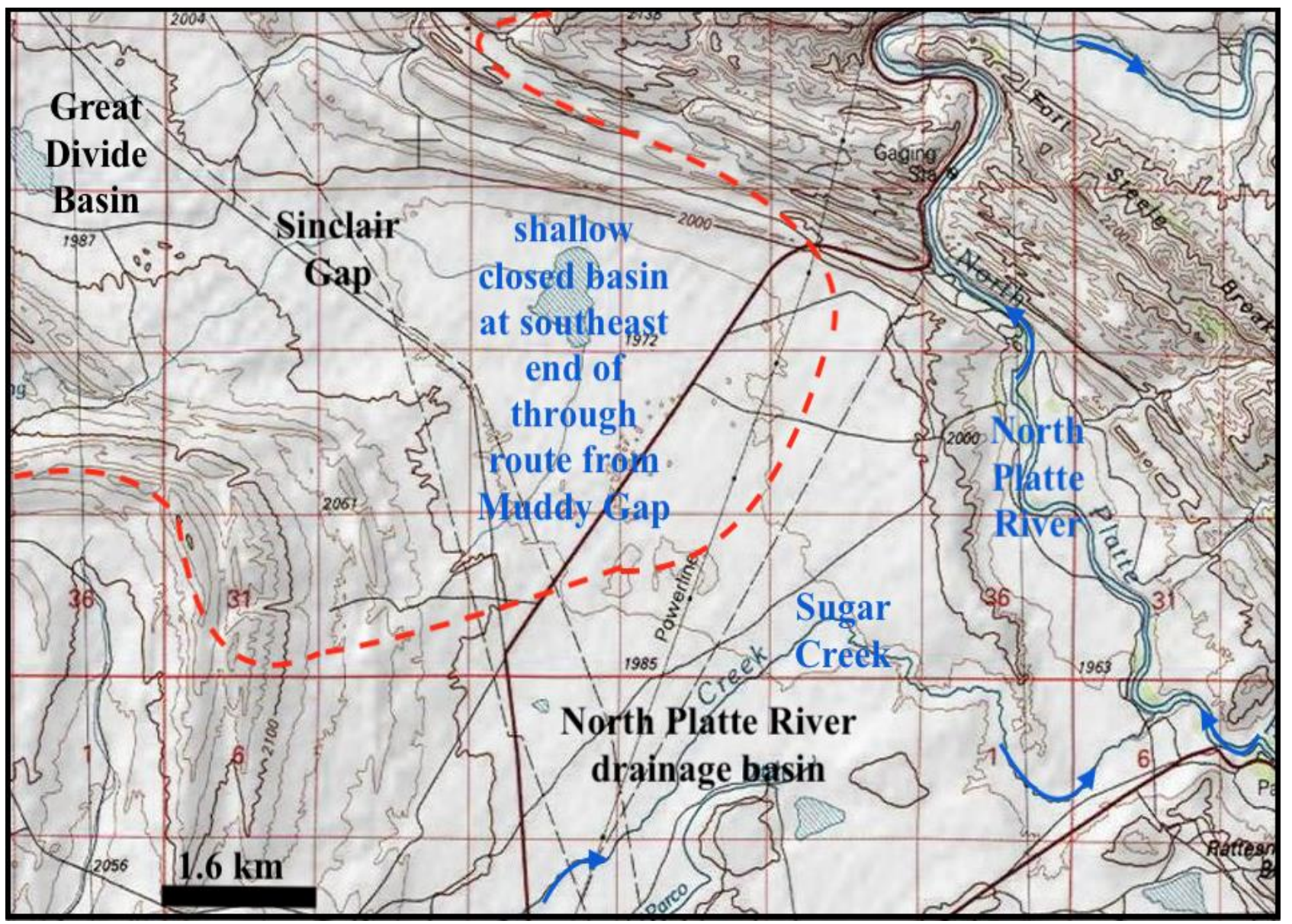

Figure 4. Modified topographic map from the USGS National Map website showing Sinclair Gap between the Rawlins Uplift (southwest) and the Haystack Mountains (north) and the north-oriented North Platte River water gap cutting between the Haystack Mountains (west) and the Fort Steele Breaks (east). Red dashed line shows Great Divide

Basin-North Platte River drainage divide. Contour interval is $20 \mathrm{~m}$

Heller et al (2010), who worked from the accepted paradigm perspective considered Sand Creek Gap to be where water last exited the Great Divide Basin and other than briefly mentioning Sinclair Gap did not discuss other divide crossings linking the Great Divide Basin and North Platte River drainage basin. Perhaps this failure was based on an interpretation by several previous investigators that the Green River had once flowed across the Great Divide Basin in an eastward direction to reach the North Platte River. If so, while not stated Heller et al may have sought to determine where the Green River exited the Great Divide Basin and may have considered Sand Creek Gap the most likely location. However, Sand Creek Gap is not the only divide crossing leading from the Great Divide Basin to the North Platte River drainage basin. Each of the many other divide crossings is a place where water once flowed in one direction or the other. If an east-oriented Green River eroded Sand Creek Gap then what other drainage routes eroded divide crossings at Coal Creek Rim, at Sinclair Gap, or at Rawlins? And the problem gets more complex when the many other eastern margin gaps, such as the dry valley between Bear Mountain and Junk Hill and the Separation Creek-Alamosa Gulch through 
valley are included. The accepted paradigm does not permit reconstructions of the multitude of drainage routes that gaps along the Great Divide Basin eastern margin indicate once moved water into or out of the Great Divide Basin.

In contrast the new paradigm requires massive south-oriented floods to have flowed across the entire Missouri River drainage basin as crustal warping raised what are now high plateau areas and mountain ranges. The North Platte River is included in the Missouri River drainage basin and the new paradigm requirement forces recognition that the present-day north-oriented North Platte River segment to the east of the Great Divide Basin developed when crustal warping forced a reversal of flow on what had been a major south-oriented flood flow route. The new paradigm requirement also forces recognition that what are today northeast-oriented North Platte River tributaries were formed by reversals of southwest-oriented anastomosing flood flow channels that had been moving water from what is today the North Platte River drainage basin into what is now the Great Divide Basin. South-oriented floodwaters moving across the Great Divide Basin's eastern area would have logically flowed through Sinclair Gap from what is now the Great Divide Basin to reach south-oriented flood flow moving on what is now the north-oriented North Platte River alignment (which prior to its reversal had been moving water across what are now high mountain passes to the Colorado River drainage basin and to the Laramie and Cache la Poudre Rivers) or in the Separation Creek-Alamosa Gulch through valley to reach the Colorado River drainage basin.

\subsection{Divide Crossings Along the Great Divide Basin's Southern Margin}

Fillmore Creek begins at the Great Divide Basin southern margin's eastern end almost in the Separation Creek-Alamosa Gulch through valley and flows in a northwest and west direction before turning in a north and northeast direction to join Separation Creek. Several well-defined divide crossings suggest streams of water once flowed across the Fillmore Creek-Muddy Creek (Great Divide Basin-Colorado River drainage basin) divide. One deeper divide crossing (floor elevation 2193) has a depth of approximately 35 meters and like the other divide crossings links north- and south-oriented valleys. To the west of the Fillmore Creek drainage area elevations along the Great Divide Basin-Colorado River drainage divide decrease and are generally less than 2100 meters with elevations in the Wamsutter Gap area decreasing to 2051 meters before rising to more than 2100 meters along the Wamsutter Rim crest. To the west of the Wamsutter Gap area the Great Divide Basin-Colorado River drainage divide is located to the north of the northwest- and southwest-oriented Bitter Creek drainage basin with Bitter Creek flowing to the south-oriented Green River (which flows to the Colorado River). Interestingly a 7-kilometer long segment of this Great Divide Basin-Bitter Creek (Colorado River) drainage divide stretch has elevations lower than 2100-meters, with the lowest elevation being about 2080 meters. Elevations along the Great Divide Basin's southern margin are remarkably similar to floor elevations of divide crossings along the Great Divide Basin's northern and eastern margins and if south-oriented Arapahoe Creek (seen in figure 2) had sufficient volumes of water that water after filling some shallow closed basins could easily overflow and continue in a south direction across the Great Divide Basin to reach many of the Great Divide Basin southern margin divide crossings and the Colorado River drainage basin.

In spite of Love's (1970) suggestion that a powerful south-oriented river entered the Great Divide Basin and suggestion that further investigation should be conducted subsequent investigators working from the accepted paradigm perspective have not described where that powerful river went. Hansen (1986) describes an east-oriented Green River, but makes no mention of a powerful south-oriented river and does not show how Great Divide Basin topographic map evidence supports such an interpretation and also ignores the Great Divide Basin south margin topographic map evidence. Heller et al (2010) reference Love's 1970 paper, but do not mention a powerful south-oriented river that once entered what is now the Great Divide Basin. Love's powerful south-oriented river must have flowed completely across the Great Divide Basin probably to reach the Colorado River drainage basin. Further, while briefly mentioning Wamsutter Gap Heller et al do not discuss how any Great Divide Basin southern margin divide crossings originated. Trying to use previously published interpretations to explain the Great Divide Basin southern margin divide crossing evidence suggests researchers working from the accepted paradigm perspective have yet to ask the correct questions, which are where did that powerful south-oriented river come from, where did it flow across the Great Divide Basin and where did it exit from the Great Divide Basin?

The new paradigm requires immense south-oriented floods to have crossed the entire Missouri River drainage basin, which includes what is today the east-oriented Sweetwater River drainage basin and such floods must have flowed into and across the Great Divide Basin. Such a requirement forces recognition that the Great Divide Basin is located along a deep "hole" rim segment formed by continental ice sheet caused crustal warping that occurred as massive south-oriented floods flowed from the continental ice sheet to and across what is now the Montana, Wyoming, and northern Colorado east-west continental divide. Uplift of that deep "hole" rim segment would have enabled the east-oriented Sweetwater River valley to erode headward across south-oriented floodwaters so as to divert flood flow along the rising deep "hole" rim in an eastward direction. At first the newly diverted east-oriented floodwaters would have joined south-oriented flood flow on what is today the north-oriented North Platte River alignment (note in figure 1 
how the Sweetwater River turns in a south direction to join the North Platte River), but as deep "hole" rim uplift proceeded flood flow on the North Platte River alignment would have been reversed to form today's north-oriented North Platte River. Assuming prior to Sweetwater River valley headward erosion south-oriented floodwaters moved in complexes of diverging and converging channels into and across the Great Divide Basin all divide crossings along the Great Divide Basin's southern margin, just like those along the northern and eastern margins, can be easily explained.

\subsection{Divide Crossings Along the Great Divide Basin's Western Margin}

Divide crossing floor elevations along the Great Divide Basin's western margin are generally higher than lowest divide crossing floor elevations along the northern, eastern, and southern margins, and like the north, east, and south margins the Great Divide Basin's western margin has more divide crossings than this finite paper can address. However, divide crossings located near the western margin's south end in the Leucite Hills area (figure 5) merit attention. The Leucite Hills are located on the Rock Springs uplift's north flank and are eroded remnants of a "Pliocene-Pleistocene" volcanic field. Note how the Colorado River-Great Divide Basin drainage divide (shown by red dashed line) crosses North Table Mountain before dropping in elevation as it crosses a 200-meter deep divide crossing to then cross the top of Steamboat Mountain. Maps by Scott and Jones (2009) and Hallberg and Case (2015) show Steamboat Mountain and North Table Mountain and South Table Mountain to have a volcanic caprock overlying Tertiary sediments. Drainage on the west side of the continental divide flows to south-oriented Killpecker Creek, which joins southwest-oriented Bitter Creek shortly before Bitter Creek joins the south-oriented Green River (which then flows to the Colorado River). The Killpecker Creek valley floor to the west of figure 5 has approximately the same elevation (about 2020 meters) as the floor of the shallow Great Divide Basin closed basin where the east-oriented drainage routes end.

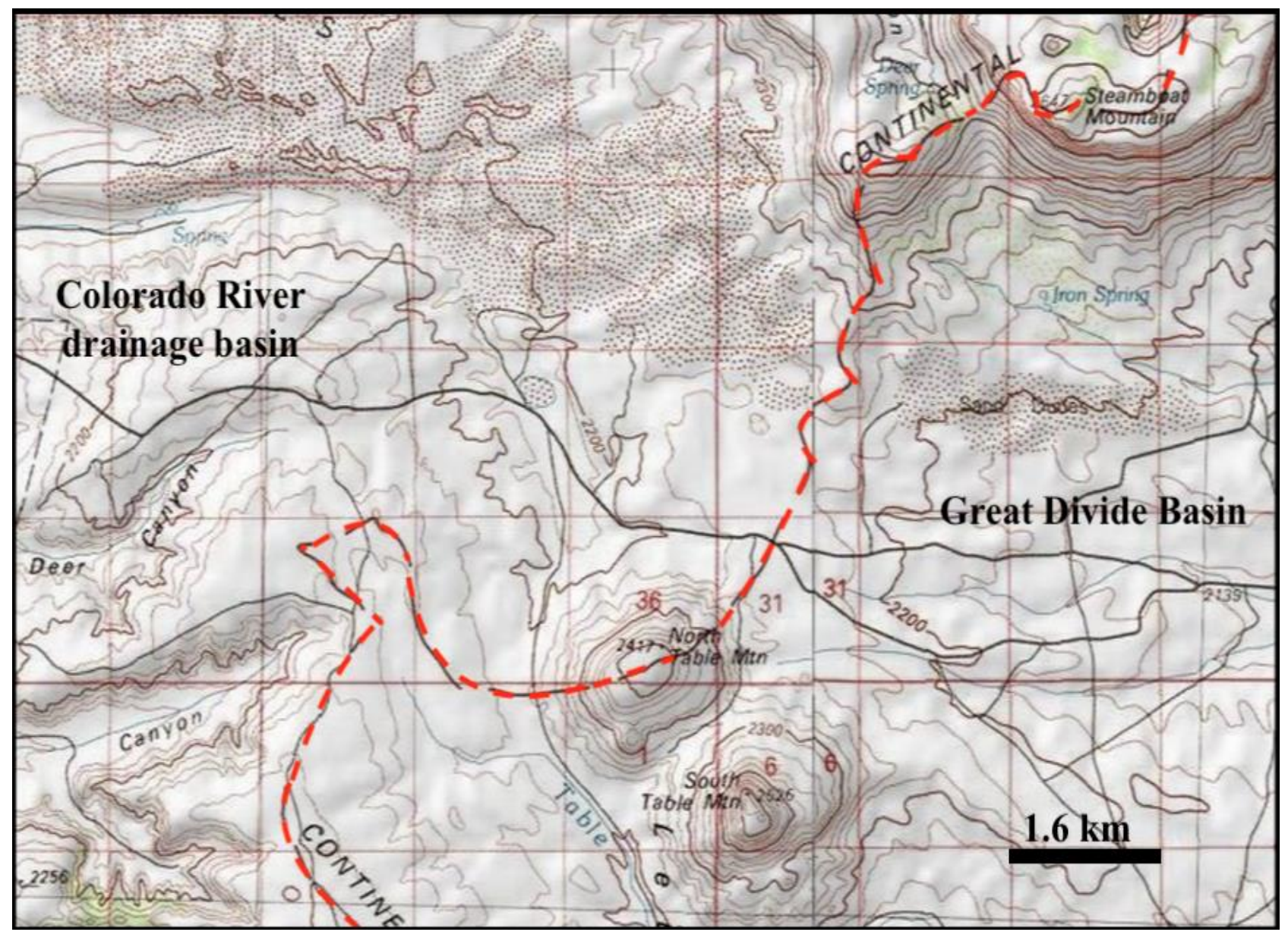

Figure 5. Modified topographic map from the USGS National Map website showing the continental divide location (red dashed line) and the 200-meter deep divide crossing between North Table Mountain and Steamboat Mountain. Westand southwest-oriented drainage flows to south-oriented Killpecker Creek, which flows to Bitter Creek and then to south-oriented Green River. The contour interval is 20 meters

Working from the accepted paradigm perspective Lange et al (2000, p. 329) state Leucite Hills "volcanic activity spanned the interval from 3.0 to $0.89 \mathrm{Ma}$ " and "there is a strong correlation... between the height of the volcanic mesas (the volcanic cap protects the underlying sediment from erosion) and their eruption age, providing an average sediment 
erosion rate of about $0.113 \mathrm{~mm} /$ year over the last 2.5 million years." They determined ages for Steamboat Mountain caprock of about 1.8 Ma, North Table Mountain caprock of about 1.4 MA, and South Table Mountain caprock of about 2.5 or 1.8 MA. These ages imply that about two million years ago Tertiary sediments capped by volcanic rocks extended across the entire figure 5 map area to a level as high as the North Table Mountain and Steamboat Mountain tops and may have extended westward across what is now the Killpecker Creek valley and eastward into and possibly across what is now the Great Divide Basin. Such basin fill is consistent with previously discussed accepted paradigm interpretations, although other than providing an erosion rate the Lange $e t$ al paper provides no clue as to how the gap between North Table and Steamboat Mountains was eroded or as to how the Killpecker Valley or the Great Divide Basin to the east were eroded. On the other hand, working from the new paradigm perspective Clausen (2019b) described how massive south-oriented floods eroded Sweetwater Gap (and other gaps) across a rising Wind River Range (to the north of the figure 5). Such floods could easily have reached the figure 5 map area with one diverging channel flowing between North Table and Steamboat Mountains while the main channel continued southward along the Killpecker Creek alignment. Headward erosion of the deep Killpecker Creek valley eventually would have captured all east- and southeast-oriented flow moving around North and South Table Mountains into what is now the Great Divide Basin and that capture would have created the present-day drainage divide.

\section{Discussion and Conclusion}

This paper describes enough divide crossings notched into drainage divides encircling the Great Divide Basin interior drainage region to demonstrate that water once flowed at numerous locations into and/or out of the Great Divide Basin. For some reason previous investigators working from the accepted paradigm perspective have failed to mention and discuss almost all of the described divide crossings. It is possible accepted paradigm rules focus investigator attention on other types of evidence and cause investigators to ignore drainage divides and places where water once flowed across those drainage divides. Rather than studying drainage divides and divide crossings several previous investigators focused their attention on a hypothesized east-oriented Green River, yet those previous investigators have not demonstrated where the Green River entered and/or exited the Great Divide Basin nor have they documented where the Green River flowed across the Great Divide Basin. Today the Green River heads in the Wind River Mountains (see figure 1) and flows in a south direction across the Green River Basin to reach Utah and then enter deep canyons as it flows across the eastern Uinta Mountains uplift. Any hypothesis suggesting the Green River once flowed across the Great Divide Basin also requires a good explanation of how a valley could erode headward across the high Uinta Mountains uplift and capture an east-oriented Green River. To date no such explanation has been offered. At best the accepted paradigm explanations are incomplete and do not explain the easy to observe erosional landform evidence.

Unlike the accepted paradigm the new paradigm by recognizing the Great Divide Basin and adjacent mountain ranges were uplifted at the same time that immense south-oriented floods flowed across the Rocky Mountains successfully explains most if not all observed drainage divide and divide crossing origins and as such provides much simpler drainage divide and divide crossing origin explanations than the accepted paradigm. However, new paradigm explanations also raise questions such as, where did the floodwaters come from and why were the floodwaters flowing across what is today the east-west continental divide at a time when that continental divide and the adjacent mountain ranges were being uplifted? The new paradigm definition (that all Missouri River drainage basin valleys eroded headward across immense south-oriented floods) forces recognition of a continental ice sheet that was heavy enough to cause significant crustal warping and to create and occupy a deep "hole" and also forces recognition that the North American east-west continental divide in Montana, Wyoming, and northern Colorado (which today is a Missouri River drainage basin drainage divide segment) originated as a deep "hole" rim segment. Meltwater floods from such a continental ice sheet would have flowed in south directions across the rising deep "hole" rim until rim uplift forced the floodwaters to first flow in an east direction (enabling the east-oriented Sweetwater River valley to capture the floodwaters by eroding headward across the south-oriented flood flow channels) and then forced massive reversals of the south-oriented flood flow back toward the ice sheet margin (e.g. see the Wind River direction change in figure 1). But such explanations lead to a fundamentally different middle and late Cenozoic regional geologic history than what previous investigators working from the accepted paradigm perspective have described.

Without question the new paradigm provides simpler explanations for the erosional landform features discussed here and based on Occam's Razor should be the preferred paradigm. However, the new paradigm success demonstrated here relates only to erosional landform evidence found in one geographic region. Other types of geologic evidence in other geographic regions led previous investigators (who used the accepted paradigm perspective) to describe a completely different middle and late Cenozoic regional geologic history than what the new paradigm interpretations discussed here suggest occurred. The new paradigm success in explaining those other types of geologic evidence has yet to be demonstrated, just as the accepted paradigm has yet to demonstrate its ability to satisfactorily explain erosional landform evidence of the type described here. While additional new and accepted paradigm testing is needed 
investigators should be aware the new paradigm can explain significant erosional landform evidence that to date the accepted paradigm has yet to satisfactorily explain.

\section{Acknowledgements}

Arthur Strahler, then at Columbia University, and Brainerd Mears, Jr., then at the University of Wyoming during the mid 1960s introduced the author to numerous unsolved drainage history problems. Preliminary work leading up to the new paradigm development was done while employed as a faculty member at Minot State University (North Dakota) where other faculty members, students, and library staff members helped to provide access to many thousands of hard-copy detailed topographic maps.

\section{References}

Anderson, D. L. (2002). Occam's razor: simplicity, complexity, and global dynamics. Proceeding of the American Philosophical Society, 146(1), 57.

Clausen, E. (2018a). Deep erosion by continental ice sheets: a northern Missouri River drainage basin perspective, North America. Current Research in Geoscience, 8, 27-38. https://doi.org/10.3844/ajgsp.2018.27.38

Clausen, E. (2018b). Geomorphic history of the Beaver Creek drainage basin as determined from topographic map evidence: eastern Montana and western North Dakota, USA. Journal of Geography and Geology, 10(3), 79-91. https://doi.org/10.5539/jgg.v10n3p79

Clausen, E. (2018c). Topographic map analysis of high elevation Black Hills through valleys linking Spearfish and Rapid Creek headwaters valleys, Lawrence County, South Dakota, USA. Journal of Geography and Geology, 10(1), 8-21. https://doi.org/10.5539/jgg.v10n1p8

Clausen, E. (2019a). Topographic map interpretation of Bighorn River-Wind River drainage divide located east of Wyoming's Wind River Canyon, USA. Universal Journal of Geoscience, 7(2), 56-67. https://doi.org/10.13189/ujg.2019.070202

Clausen, E. (2019b). Use of topographic map evidence to test a recently proposed regional geomorphology paradigm: Wind River-Sweetwater River drainage divide area, Central Wyoming, USA. Open Journal of Geology, 9, 404-423. https://doi.org/10.4236/ojg.2019.98027

Clausen, E. (2019c). How a fundamentally different and new glacial history paradigm explains North America glaciated prairie region erosional escarpments and drainage patterns. Earth Science Research, 8(2), 23-34. https://doi.org/10.5539/esr.v8n2p23

Clausen, E. (2019d). Use of stream and dismembered stream valleys now crossing Wyoming's northern Laramie Mountains to test a recently proposed regional geomorphology paradigm, USA. Open Journal of Geology, 9, 731-751. https://doi.org/10.4236/ojg.2019.98027

Conroy, G. C., Anemone, R. L., Van Regenmorter, J., \& Addison, A. (2008). Google Earth, GIS, and the Great Divide: a new and simple method for sharing paleontological data. Journal of human evolution, 55(4), 751. https://doi.org/10.1016/j.jhevol.2008.03.001

Fan, M., Heller, P., Allen, S. D., \& Hough, B. G. (2014). Middle Cenozoic uplift and concomitant drying in the central Rock Mountains and adjacent Great Plains. Geology, 42(6), 547-550. https://doi.org/10.1130/G35444.1

Flanagan, K. M., \& Montagne, J. (1993). Neogene stratigraphy and tectonics of Wyoming. In Snoke, A. W., Steidtmann, J. R., and Roberts, S. M. (eds) Geology of Wyoming. Geological Survey of Wyoming Memoir, 5, 597-598

Hallberg, L. L., \& Case, J. C. (2015). Preliminary surficial photogeologic map of the Red Desert Basin 30' x 60' quadrangle, Sweetwater County, Wyoming. Wyoming State Geologic Survey, Open File Report 15-4, scale 1:100,000. https://doi.org/10.3133/ofr72309

Hansen, W. R. (1986). Neogene tectonics and geomorphology of the eastern Uinta Mountains in Utah, Colorado, and Wyoming. United States Geological Survey, Professional Paper;(USA), 75(1356). https://doi.org/10.3133/pp1356

Heller, P. L., McMillan, M. E., \& Humphrey, N. (2010). Climate-induced formation of a closed basin: Great Divide Basin, Wyoming. Geological Society of America Bulletin, 123(1-2), 150-157. https://doi.org/10.1130/B30113.1

Jaworowski, C. (1991). Green Mountain-Sweetwater River area. In Morrison, R. B. (Ed), Quaternary nonglacial geology: conterminous U.S. volume K-2. Geological Society of America, 417-418.

Kuhn, T. S. (2012). The structure of scientific revolutions. University of Chicago press.

Lange, R. A., Carmichael, I. S. E., \& Hall, C. M. (2000). ${ }^{40} \mathrm{Ar} r^{39} \mathrm{Ar}$ chronology of the Leucite Hills, Wyoming: eruption rates, erosion rates, and an evolving temperature structure of the underlying mantle. Earth and Planetary Science 
Letters, 174(3-4), 329-340. https://doi.org/10.1016/S0012-821X(00)00093-5

Lillegraven, J. A., \& Ostrech, L. M. Jr. (1988). Evolution of Wyoming's early Cenozoic topography and drainage patterns. National Geographic Research, 4, 303-327.

Love, J. D. (1970). Cenozoic geology of the Granite Mountains area, central Wyoming (No. 495-C). https://doi.org/10.3133/pp495C

Love, J. D. (1971). Relation of Cenozoic geologic events in the Granite Mountains area, central Wyoming, to economic deposits, In Symposium on Wyoming tectonics and their economic significance. Wyoming Geological Association Guidebook, 23 ${ }^{\text {rd }}$ Annual Field Conference, 71-80. https://doi.org/10.3133/pp495C

Love, J. D., \& Christiansen, A. C. (1985). Geologic map of Wyoming. United States Geologic Survey, Wyoming State Geological Survey 2014 release.

McLaughlin, J. F., \& Fruhwirth, J. (2008). Preliminary geologic map of the Rawlins 30’ x 60' quadrangle, Carbon and Sweetwater Counties, southeastern Wyoming. Wyoming Geological Survey, Open File Report OFR 08-4, scale 1:100,000. https://doi.org/10.3133/ofr74179

Mears Jr, B. (1993). Geomorphic history of Wyoming and high-level erosion surfaces. Geology of Wyoming: Laramie, Geological Survey of Wyoming Memoir, 5, 608-626.

Rackley, R. I. (1972). Environment of Wyoming Tertiary uranium deposits. American Association of Petroleum Geologists Bulletin, 56(4), 755-774. https://doi.org/10.1306/819A4080-16C5-11D7-8645000102C1865D

Scott, J. E., \& Jones, R. W. (2009). Preliminary geologic map of the Rock Springs Quadrangle, Wyoming Geological Survey, Open File Report 09-4, scale 1:100,000. https://doi.org/10.3133/ofr76229

Steidtmann, J. R., Middleton, L. T., \& Shuster, M. W. (1989). Post Laramide (Oligocene) uplift in the Wind River Range, Wyoming. Geology, 17(1), 38-41. https://doi.org/10.1130/0091-7613(1989)017<0038:PLOUIT>2.3.CO;2

\section{Copyrights}

Copyright for this article is retained by the author(s), with first publication rights granted to the journal.

This is an open-access article distributed under the terms and conditions of the Creative Commons Attribution license (http://creativecommons.org/licenses/by/4.0/). 